\title{
SISTEM PAKAR UNTUK IDENTIFIKASI PENYAKIT SAYURAN KUBIS MENGGUNAKAN FORWARD CHAINING BERBASIS GUI
}

\section{HANY ALROZY IRACHMAN}

Teknik Informatika, Fakultas Teknik

Universitas Maarif Hasyim Latif, Sidoarjo, Indonesia

e-mail : hany-alrozy-irachman@student.umaha.ac.id

\section{ABSTRAK}

Tanaman Kol (brassica oleraceae) merupakan tanaman jenis sayuran yang berasal dari dataran tinggi berpengaruh dalam ekonomi. Kubis untuk fungsi obat atau herbal kubis dapat dijadikan sebagai obat melonggarkan tekanan darah sehingga dapat terkontrol, mineral kubis juga berfungsi untuk tulang sehat mencegah osteoporosis, untuk mencegah kanker, dikarenakan kubis mengandung antioksidan. Sistem pakar termasuk adalah sistem yang berfungsi untuk kenyataan dan teknik berpikir sehingga bisa mengambil keputusan agar bisa menyelesaikan masalah yang dapat dikerjakan oleh ahlinya dalam bidang yang bersangkutan, sistem pakar menggabungkan penarikan kesimpulan dengan pengetahuan yang diberikan pakarnya, kombinasi dari keduanya disimpan kemudian dipergunakan mengambil keputusan dan ketemu masalahnya. Dalam ini Sistem menggunakan rancangan metode forward chaining untuk memberikan pertimbangan kepada petani sehingga dapat menentukan jenis unggul, hasil berupa kepastian jawaban fakta yang ada berfungsi untuk mesin infrensi, penelitian diukur tingkat keakurasiannya sebesar $80 \%$ sehingga sistem didapat berhasil diterapkan mendiagnosa penyakit kubis.

Kata kunci : forward chaining, sistem pakar, kol

\section{PENDAHULUAN}

Kol (brassica oleraceae) adalah salah satu sayuran yang banyak mendapatkan perhatian karena memiliki nilai ekonomis yang dibutuhkan oleh semua orang di Indonesia karena manfaat kubis yang dibutuhkan banyak orang beberapa tahun ini banyak petani yang menanam kubis sebagai alternatif sebagai bercocok tanam, cara perawatan yang tidak benar dengan standart akan mengakibatkan tanaman kol rentan penyakit dan bisa mengakibatkan hasil panen tidak maksimal, hasil rendah penjualan dan dapat berakibat panen gagal, hama yang menyerang kubis adalah hama ulat, lalat dan lain-lain, hama tersebut bisa berakibat tanaman kubis terkena penyakit.

Penyakit yang paling sering menyerang kubis adalah layu daun, busuk akar, buah dan bunga. Indonesia mulai banyak petani yeng budi daya kubis hijau, dan hal tersebut terkadang untuk bercocok tanam yang lebih dikenal dengan mata pencaharian dari menanam kubis, tetapi masih ada petani yang belum bisa menanam kubis dengan sesuai standart, sehingga mudahnya serangan hama penyakit, dan kebanyakan kurang mengetahui pastinya jenis penyakit, hama yang sedang mengenai kubis. biasanya para petani cuma menduga penyakit apa yang menyerang kubisnya dan mencoba mencari pengobatan alternatif dan itu bisa merugikan para petani karean kubisnya mati, oleh karena itu petani membutuhkan ilmu penegtahuan dari pakar yang dapat meningkatkan kualitas dalam menanam dan juga meningkatkan harga jual kubis. Pengetahuan yang akan diperoleh ke dalam sistem pakar adalah dengan digunakannya data yang berpindah sampai ditentukannya objek dengan forward chaining.

\section{METODOLOGI PENELITIAN}

Definisi sistem pakar adalah perangkat lunak yang memakai ilmu teknik dan fakta yang berpikiran untuk mengambil suatu berputusan yang bisa terselesaikan oleh ahlinya dalam bidangnya, sistem pakar menggabungkan kesimpulan dengan basis pengetahuan yang didapat oleh pakar itu sendiri, kemudian akan disimpan dan digunakan diproses mengambil putusan untuk mendapatkan masalahnya. Penulis akan membahas mengenai metode penelitian yang akan digunakan pada identifikasi penyakit kubis menggunakan forward chaining berbasis GUI. Forward Chaining adalah teknik mencari menggunakan fakta yang telah dimengerti, setalah itu fakta tersebut dapat dipadukan dengan IF yang terdapat dari IF-THEN.

Apabila ada fakta yang padu dengan IF, maka akan diselesaikan, setelah padu maka akan ada fakta baru pada THEN yang ditambahkan ke basis data Untuk dapat mencapai hasil yang akurat dan maksimal, maka akan melalui beberapa tahapan proses yang terstruktur. Tahapannya akan ditampilkan. 


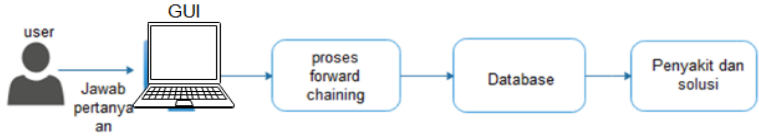

Gambar 1 Blok Diagram Perancangan Sistem

Pada gambar 1 User mengirimkan informasi dan konsultasi kepada sistem pakar dengan cara menjawab pertanyaan-pertanyaan gejala penyakit yang telah ditentukan oleh pakar, kemudian GUI menampilkan informasi berupa laporan yang meliputi data kubis, gejala penyakit kubis serta solusi penanganan kubis, dilanjutkan dengan database data kubis akan diproses dan dijadikan menjadi satu, terakhir akan diproses forward chaining kemudian akan menghasilkan output penyakit dan solusi.

\section{Diagram Alur}

Tahap pertama adalah cara menginisialisasi penelitia bermula pada pendataan problem yang dilakukan, mendata penyakit tanaman kol, melakukan wawancara dengan para petani, penjual, dan pupuk hama dan melakukan sharing dengan ahli pertanian. Tahap kedua adalah analisis dan merancang. Pada tahap ini cara menganalisis penyakit, gejala-gejala pada tanaman kol, dan terakhir dilakukan pada tahap ini adalah aturan perancancangan yang diperlukan untuk sistem pakar tersebut. Terakhir adalah tahap implementasi dan uji coba. Pada tahap ini dibuat sistem berupa peraturan yang telah dibuat, kedua habis itu melakukan percobaan terhadap sistem dengan cara menakar akurasi dari sistem.

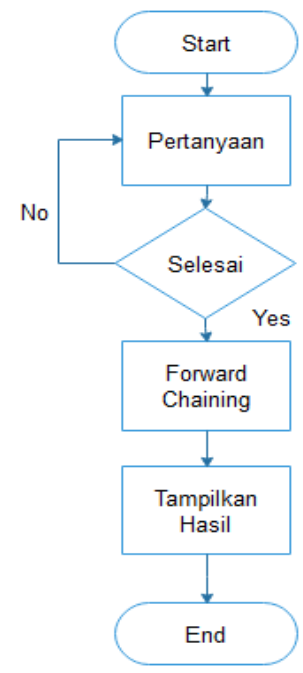

Gambar 2 Diagram Alur

\section{USE CASE Diagram}

Pertama melakukan konsultasi penyakit terlebih dahulu apa yang mau ditanyakan dan disertai keluhan yang terjadi, kemudian dari data yang sudah dikumpulkan akan didapat dan dicocokkan solusi yang terjadi dari penyakit yang ditanyakan.

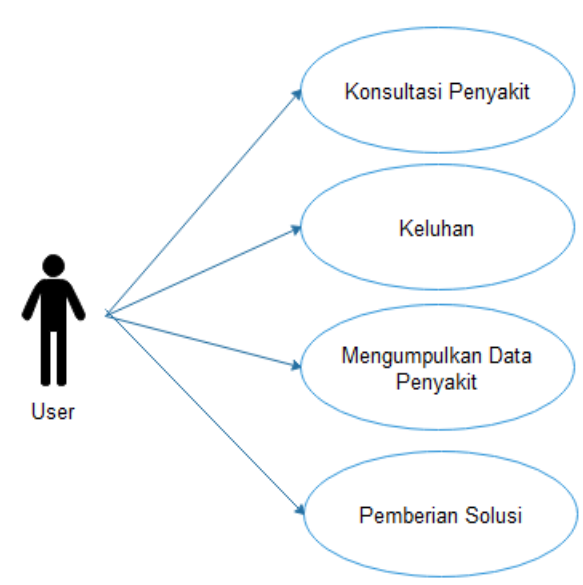

Gambar 3 Use case Diagram

\section{Daftar Nama Penyakit dan Penanganan}

Berikut tabel 1 adalah daftar nama penyakit yang berjumlah 14 penyakit dan per penyakit sudah ada solusinya langsung yang berkode P1 P14 disajikan pada tabel Daftar Nama penyakit dan solusi.

Tabel 1 Daftar Nama Penyakit

\begin{tabular}{|c|c|c|}
\hline penyakit & solusi & kode \\
\hline Layu Fusarium & Lakukan pengapuran tanah pada saat pengolahan tanah, terutama lahe & \\
\hline Bercak Daun Septoria & Gulma, tanaman kubis yang mati dibersihkan dan dibakar, semprot tar & P2 \\
\hline Bercak Coklat & Disemprot dengan fungisida yang efektif, seperti Brestan $6072 \mathrm{WP}$, Di & P3 \\
\hline Busuk Daun & Mengatur waktu tanam dimusim kemarau, disemprot fungisida sepert & P4 \\
\hline Busuk Buah Rhizoctonia & Gulma, tanaman kubis yang terserang penyakit dicabut dan dibakar, $s \in$ & P5 \\
\hline Busuk Buah Antraknosa & Melakukan sistem tumpang sari tanaman selama 1-2 tahun, menyemp & P6 \\
\hline Layu & Semprotkan antibiotik pada bibit tanaman kubis & P7 \\
\hline Bercak Bakteri & Tanaman kubis yang terserang penyakit dicabut dan dibakar di area yal & P8 \\
\hline Bercak Daun & Semprotkan antibiotik pada bibit tanaman kubis & P9 \\
\hline Antraknos & Melakukan sistem tumpang sari tanaman selama 1-2 tahun & $\mathrm{P} 10$ \\
\hline Layu Cendawan & Mencabut tanaman yang sakit agar tidak menular & P11 \\
\hline Layu Bakteri & Aplikasikan beberapa Fungisida Hayati seperti Anfush dan Decoprima & P12 \\
\hline Bercak (Bacterial speck) & Tanaman kubis yang terserang penyakit dicabut dan dibakar di area yal & P13 \\
\hline Mozaik & Pemberian imunisasi pada kubis & P14 \\
\hline
\end{tabular}

\section{Sequence Diagram}

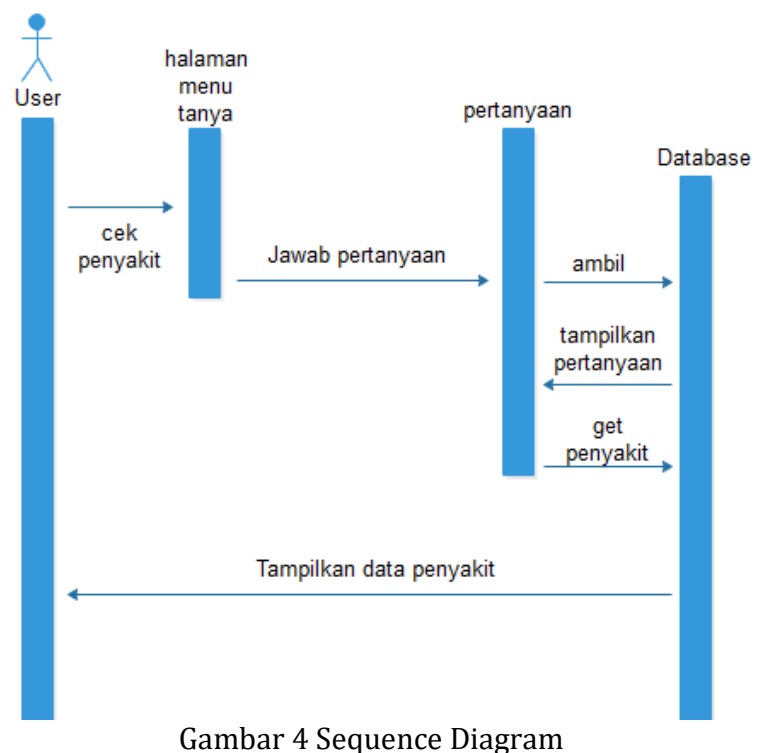

Menggambarkan interaksi antara sejumlah objek dalam urutan waktu. Kegunaannya untuk menunjukkan rangkaian pesan yang dikirim antara 
objek juga interaksi antar objek yang terjadi pada titik tertentu dalam eksekusi sistem, pertama User masuk kedalam menu gejala Kedua User memilih gejala penyakit yang sesuai, ketiga Konsultasi melakukan proses diagnosis, keempat Kemudian objek hasil diagnosis menampilkan hasil diagnosis sesuai gejala penyakitnya dan solusinya seperti pada Sequence diagram gambar 4 .

\section{ERD (Entity Relationship Diagram)}

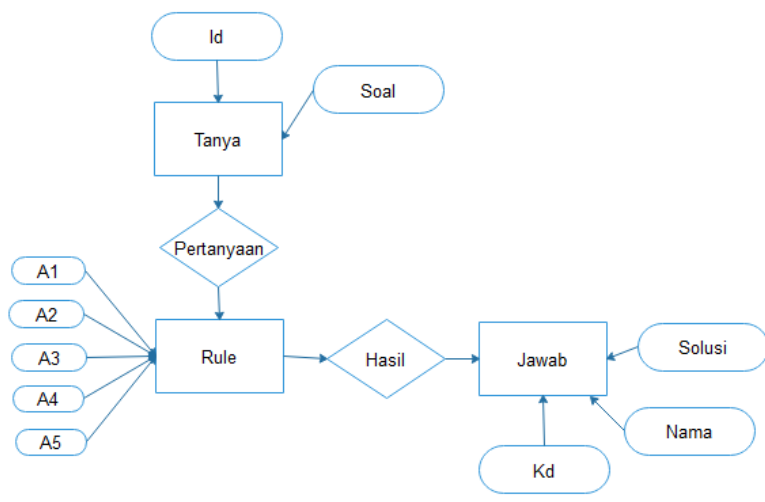

Gambar 5 ERD

Keterangan, relasi pertanyaan digunakan untuk memunculkan isi dari atribut soal yang ada didalam table tanya berdasarkan ID yang direlasikan dengan table rule pada atribut A1, A2, A3, A4, A5. Sedangkan untuk relasi hasil digunakan untuk memunculkan nama penyakit dan solusi dari tabel jawab berdasarkan kode penyakit yang direlasikan dengan table rule.

\section{Class Diagram}

Dari sequence diagram ada 4 kelas yang saling berinteraksi yaitu halaman database, halaman admin, sistem, database. Kelas Diagram dapat memberi pertanda hubungan antar kelas dalam sistem yang telah dibangun dan bagaimana kelas tersebut bergabung untuk mencapai suatu tujuan, Class Diagram sistem pakar identifikasi penyakit kol.

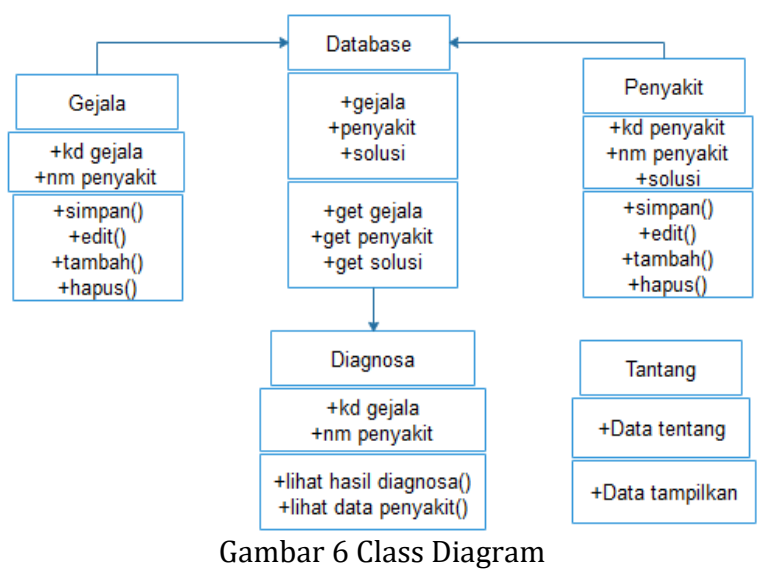

Pertama user masuk mengakses aplikasi sistem pakar, kemudian GUI mampu menampilkan pertanyaan untuk mendiagnosa gejala pada penyakit kubis dan menampilkan hasil prosentase penyakit kuis serta solusi atau penanganan pada penyakit kubis, setelah itu sistem sebagai proses pengolah data dan mengumpulkan fakta untuk menyimpulkan penanganan penyakit kubis.

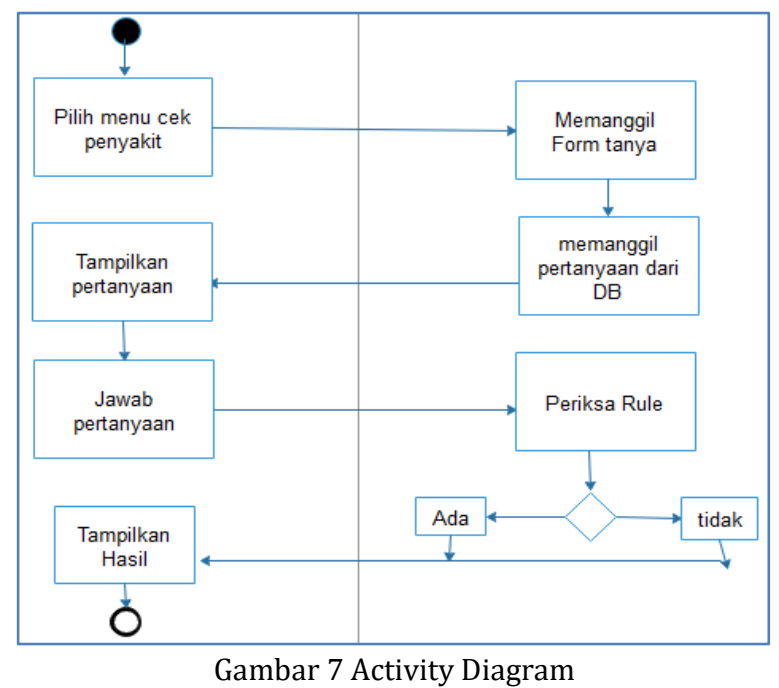

\section{IMPLEMENTASI DAN UJI COBA}

Dapat disimpulkan tabel database rule untuk mencari tahu tanaman yang terkena gejala penyakit sehingga dapat mencocokkan dengan nama penyakit dan solusinya, jika memilih gejala yang seperti pada tabel di bab 3 misal dalam tabel pertanyaan a1, a2, a4, a15 maka akan diaktifkan dan dapat memanggil sesuai gejala tadi sehingga dapat menghasilkan jawaban P1, tipe data bisa dilihat pada Tabel 2.

Tabel 2 Data Rule

\begin{tabular}{|c|c|c|c|c|c|c|c|c|c|c|c|c|c|c|c|c|}
\hline a1. & a2. & a3 & - $a 4$ & & $25 \cdot a$ & 96 . & a7 & a8 & & a9. & - & . & 12 & & $13=-914$ & thade \\
\hline 1 & 1 & 1 & 0 & 1 & 0 & 0 & & 0 & 0 & & 0 & 0 & 0 & 0 & 0 & $1 \mathrm{P} 1$ \\
\hline 1 & 0 & 0 & 1 & 0 & 1 & 0 & & 0 & 0 & & 0 & 0 & 0 & 0 & 0 & 0 P2 \\
\hline 1 & 1 & & 0 & 1 & 0 & 1 & & 1 & 0 & & 0 & 0 & 0 & 0 & 0 & 0 P3 \\
\hline 1 & 0 & 0 & 0 & 0 & 0 & 1 & & 1 & 0 & & 0 & 0 & 0 & 0 & 0 & $0 \mathrm{P} 4$ \\
\hline 0 & 0 & 0 & 0 & 0 & 0 & 1 & & 1 & 1 & & 0 & 0 & 0 & 0 & 0 & 0 P5 \\
\hline 1 & 0 & 0 & 1 & 0 & 0 & 0 & & 0 & 1 & & 1 & 0 & 0 & 0 & 0 & 0 P6 \\
\hline 1 & 1 & 1 & 1 & 1 & 0 & 0 & & 0 & 0 & & 0 & 1 & 0 & 0 & 0 & $1 \mathrm{P} 7$ \\
\hline 1 & 0 & 0 & 1 & 0 & 1 & 0 & & 0 & 1 & & 0 & 0 & 0 & 0 & 0 & 0 P8 \\
\hline 1 & 1 & 1 & 0 & 0 & 1 & 0 & & 0 & 0 & & 0 & 1 & 0 & 0 & 0 & 0 P9 \\
\hline 0 & 0 & 0 & 0 & 0 & 0 & 1 & & 1 & 0 & & 0 & 0 & 0 & 0 & 0 & 0 P 10 \\
\hline 1 & 1 & 1 & 0 & 0 & 0 & 0 & & 0 & 0 & & 1 & 0 & 0 & 0 & 0 & 0 P11 \\
\hline 1 & 1 & 1 & 1 & 0 & 0 & 0 & & 0 & 0 & & 1 & 0 & 0 & 0 & 0 & 0 P12 \\
\hline 0 & 0 & 0 & 0 & 0 & 0 & 1 & & 0 & 0 & & 0 & 0 & 0 & 0 & 0 & 0 P13 \\
\hline 1 & 1 & 1 & 0 & 0 & 0 & 0 & & 0 & 0 & & 0 & 0 & 1 & 0 & 0 & O P14 \\
\hline
\end{tabular}

Dapat disimpulkan Data Pertanyaan berfungsi untuk menyambungkan ke gejala yang dipilih misal memilih gejala A1 maka akan tampil pertanyaan pertama dan seterusnya sampai A14 = pertanyaan 14 dan itu bisa ditambahi ataupun dikurangi oleh admin.

\section{Activity Diagram}


Tabel 3 Data Pertanyaan soal

1 Apakah tanaman layu?

2 Apakah daun muda dan daun tua tanaman warnanya kuning?

3 Apakah daun tanaman menggulung, mengering dan rontok?

4 Apakah tanaman menjadi mati?

5 Apakah terdapat bercak kecil berair pada daun?

6 Apakah buah tanaman menjadi busuk?

7 Apakah pangkal buah berwarna coklat?

8 Apakah terdapat bercak cekung coklat pada buah?

9 Apakah akar dan batang tanaman berwarna coklat?

10 Apakah tanaman terlihat kerdil?

11 Apakah daun tanaman keriting, kerdil dan melengkung?

12 Apakah Tanaman Seperti Kekurangan Air?

13 Apakah Tulang Daun Tanaman Seperti Pucat?

14 Apakah tangkai daun tanaman merunduk?

Database jawaban ini berfungsi menghubungkan atau memanggil apabila telah memilih beberapa pertanyaan yang sesuai dengan tabel Rule tadi maka akan muncul jawaban seperti pada tabel berupa nama penyakit dan solusi yang terjadi pada tanaman kubis,

\begin{tabular}{|c|c|c|}
\hline - penyakit & solusi & kode \\
\hline 1 Layu Fusarium & Lakukan pengapuran tanah pada saat pengolahan tanah, terutama lahe & P1 \\
\hline 2 Bercak Daun Septoria & Gulma, tanaman kubis yang mati dibersihkan dan dibakar, semprot tar & \\
\hline 3 Bercak Coklat & Disemprot dengan fungisida yang efektif, seperti Brestan $6072 \mathrm{WP}$, Di & i P3 \\
\hline 4 Busuk Daun & Mengatur waktu tanam dimusim kemarau, disemprot fungisida sepert & \\
\hline 5 Busuk Buah Rhizoctonia & Gulma, tanaman kubis yang terserang penyakit dicabut dan dibakar, $s \in$ & $\in \mathrm{P} 5$ \\
\hline 6 Busuk Buah Antraknosa & Melakukan sistem tumpang sari tanaman selama 1-2 tahun, menyemp & \\
\hline 7 Layu & Semprotkan antibiotik pada bibit tanaman kubis & P7 \\
\hline 8 Bercak Bakteri & Tanaman kubis yang terserang penyakit dicabut dan dibakar di area yal & ai P8 \\
\hline 9 Bercak Daun & Semprotkan antibiotik pada bibit tanaman kubis & p9 \\
\hline 10 Antraknos & Melakukan sistem tumpang sari tanaman selama 1-2 tahun & P10 \\
\hline 11 Layu Cendawan & Mencabut tanaman yang sakit agar tidak menular & P11 \\
\hline 12 Layu Bakteri & Aplikasikan beberapa Fungisida Hayati seperti Anfush dan Decoprima & P12 \\
\hline 13 Bercak (Bacterial speck) & Tanaman kubis yang terserang penyakit dicabut dan dibakar di area yal & al P13 \\
\hline 14 Mozaik & Pemberian imunisasi pada kubis & P14 \\
\hline
\end{tabular}

\section{Tampilan Halaman Awal}

Dalam pengerjaan aplikasi tugas akhir, pada tampilan awal terdapat dua menu, yaitu menu cek penyakit dan menu tentang program itu sendiri seperti pada gambar 8 .
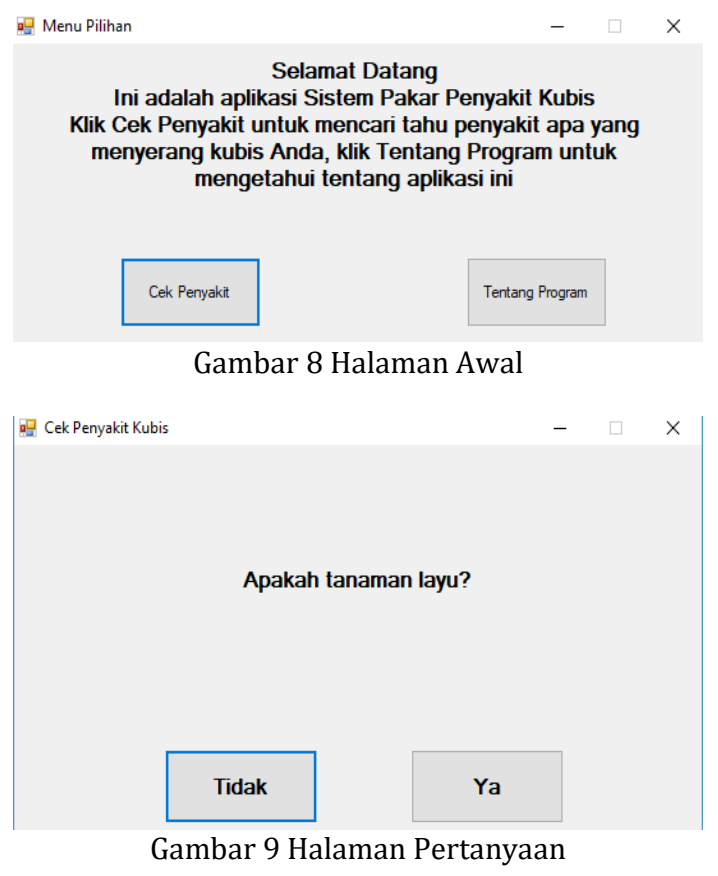

\section{Tampilan Pertanyaan Gejala}

Di dalam tampilan pertanyaan gejala akan dihadapkan dengan beberapa pertanyaan gejala penyakit kubis, pertanyaan tersebut ada 14 pertanyaan seperti gambar 9.

Disini pertanyaan dibatasi sampai dengan 14 pertanyaan yang kemudian disimpan pada listbox, agar pertanyaan dapat terlihat semua maka diperlukan listbox untuk menyimpannya.

\section{Tampilan Jawaban Solusi}

Pada tampilan jawaban solusi adalah dimana jawaban yang benar akan mencari tahu sesuai dengan database yang sudah disimpan yang didalamnya berupa nama penyakit dan solusinya, contoh tampilan jawaban solusi dapat dilihat pada gambar 10.

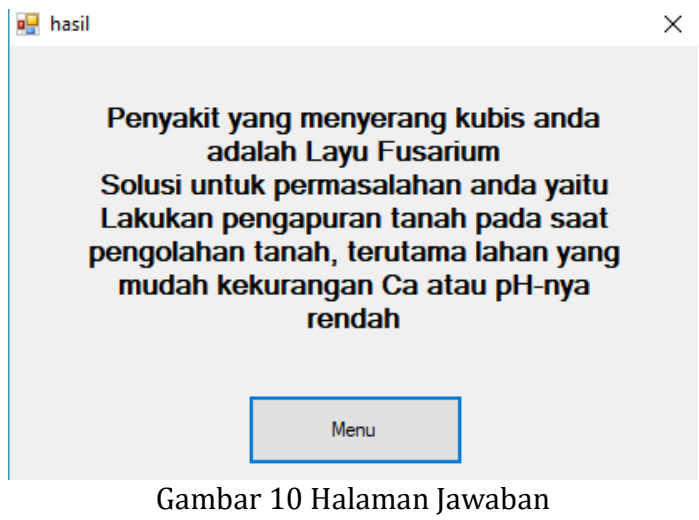

\section{Tampilan Jawaban Tidak Sesuai}

Apabila memilih tidak sesuai tabel yang ada pada tabel database maka yang tampil "data penyakit tidak ditemukan" oleh karena itu kita harus benar-benar memperhatikan data tabel database dan pertanyaan, contoh tampilan jawaban tidak sesuai seperti gambar 11 .

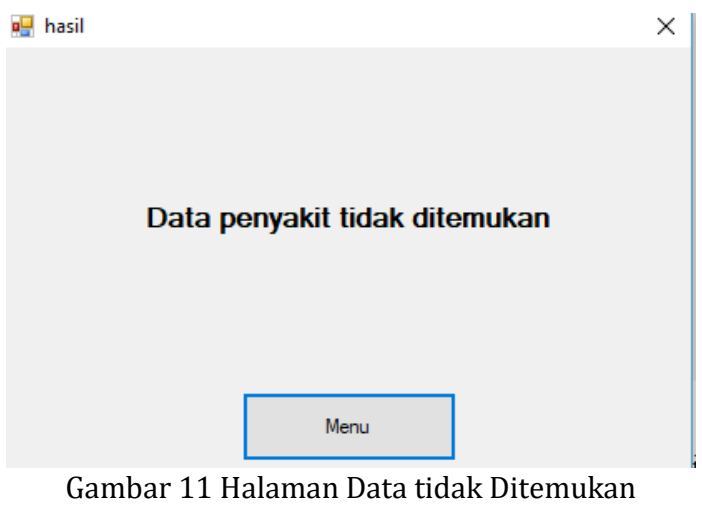

\section{Hasil Uji Coba}

Keterangan, Disini dari 7 petani 4 diantaranya setuju dengan aplikasi ini, oleh karena itu program diharapkan bisa digunakan, untuk kekurangan agar segera bisa diperbaiki, untuk perhitungan $4 / 7 \times 100=57 \%$ untuk petani yang sependapat dengan aplikasi. 
Tabel 5 Hasil Uji Coba Di Lapangan

\begin{tabular}{l|l|l|l|l}
\hline \multicolumn{1}{c|}{ Nama Petani } & \multicolumn{1}{c|}{ Alamat } & \multicolumn{1}{c|}{ Hasil } & \multicolumn{1}{c}{ Alasan } & \multicolumn{1}{c}{ Saran } \\
\hline Bpk. Asman & Desa Wonoayu & Tidak Sesuai & ada gejala dan hasil tidak sesuai & Bisa tambahkan rule lagi \\
\hline Bpk. Suyatno & Desa Tarik & Sesuai & Gejalanya cocok & $\begin{array}{l}\text { ditingkatkan, agar dipakai di } \\
\text { semua platform }\end{array}$ \\
\hline Bpk. Saiin & Desa Sumput & Tidak Sesuai & $\begin{array}{l}\text { Karena Ds. Sumput termasuk } \\
\text { dataran rendah }\end{array}$ & $\begin{array}{l}\text { Tambahan untuk kubis dataran } \\
\text { renda }\end{array}$ \\
\hline Ibu Sianah & Desa Wringinanom & Sesuai & Solusinya tepat dengan gejala & Kurang efeisien \\
\hline Bpk. Suwarno & Desa Balongbendo & Sesuai & Tidak ada alasan & Kurang efisien \\
\hline Ibu minah & Desa Mojosari & Sesuai & Tidak ada alasan & Tambahkan gejala lagi \\
\hline Bpk. yasin & Desa Prambon & Tidak Sesuai & Perbedaan gejala dan penyakit & Data perlu ditambahi \\
\hline
\end{tabular}

\section{PENUTUP}

Selain memberi solusi penanganan pada Penyakit Kubis menurut gejala yang dialami, aplikasi yang dirancang juga dapat menentukan presentase penyakit kubis yang didasari infomasi dari pakar dengan hasil persentase $80 \%$. Supaya petani lebih efisien maka perlu ditambahkan data kelengkapan penyakit kubis.

Hasil uji coba masih bisa dikembangkan lagi apabila ada data yang lebih kompleks dari pakar baik dari dinas pertanian maupun dari buku referensi tentang solusi penyakit kubis agar akurasinya menjadi semakin baik.

\section{DAFTAR PUSTAKA}

[1] M. L. Fitriani, "Budidaya tanaman kubis bunga (Brassica oleraceae var botrytis L.) di kebun benih hortikultura (KBH) Tawangmangu," Universitas Sebelas Maret: Program D3 Agribisnis Hortikultura dan Arsitektur Pertamanan, 2009.

[2] S. D. Bentley et al., "Complete genome sequence of the model actinomycete Streptomyces coelicolor A3 (2)," Nature, vol. 417, no. 6885, pp. 141-147, 2002.

[3] V. M. Yonatha and N. H. Purnomo, "Ketahanan Pangan Keluarga Pra Sejahtera di Desa Temuireng Kecamatan Dawarblandong Kabupaten Mojokerto," Swara Bhumi, vol. 5, no. 8, pp. 7-12, 2019.

[4] A. Marlyaningrum, "Aplikasi Sistem Pakar Diagnosis pada Sistem Komputer," Universitas Widyatama: Sistem Informasi, 2013.

[5] Badan Pusat Statistik, Data produksi tanaman pangan dan hortikultura. Jakarta: Pusat Data Statistik Pertanian, 2015.

[6] Dinas Pertanian, Peternakan. 2011. Laporan Tahunan. Kabupaten Indramayu, 2017.

[7] R. Rukmana, Budidaya kubis bunga \& brocoli. Yogyakarta: Kanisius, 1994.

[8] J. Kusnanto, T. S. K. Dewi, A. Budiyono, E. Suprapti, and Haryuni, "Uji Efikasi Insektisida Bahan Aktif Permetrin 300 g/l Terhadap Populasi Hama Ulat Daun (Plutella xylostella L) Pada Tanaman Kubis (Brassica oleracea)," J. IIm. Agrineca, vol. 19, no. 2, 2019.
[9] Marimin, Teori dan Aplikasi Sistem Pakar dalam Teknologi Manajerial. Bogor: IPB Press, 2009.

[10] J. Irawan, Buku Pegangan Kuliah: SISTEM PAKAR. Surabaya: Sekolah Tinggi Manajemen Informatika dan Teknik Komputer - STIKOM Surabaya, 2006. 
Ubiquitous: Computers and its Applications Journal

ISSN 2622-7983 online Volume 3, Nomor 2, Desember 2020, 71-76 